\title{
MINERALOGY OF RECENT PELITIC SEDIMENTS FROM THE FISKENÆSSET REGION, SOUTHERN WEST GREENLAND
}

\author{
Dietrich Heling
}

\section{Introduction}

Recent muds were sampled during the summer of 1973 from different fjords and lakes in the Fiskenæsset region of southern west Greenland. The samples were analysed for their mineralogical composition in order to study sorting effects and possible mineral alteration by transport action under subarctic climatic conditions. In an investigation of the composition of sands from the Fiskenæsset region Kalsbeek et al. (1974) revealed a close correspondence between the mineralogical composition of the coarser clastic components and that of the bedrock. Such relationships occur when chemical weathering of the sediment material is negligible due to low temperatures and in connection with fast transport (high relief) and corresponding high sedimentation rates. All these influencing factors are active in southern west Greenland.

Sampling was undertaken in Buksefjorden, Sermilik, Grædefjord, Fiskenæsfjorden, Bjørnesund and at the margin of Frederikshåbs Isblink. Further bottom samples were taken from the lakes marked in fig. 45. A total of 121 samples were recovered from depths ranging from 0 to $275 \mathrm{~m}$ using grab sampling devices.

Almost the entire sediment material under consideration has been produced by glacial abrasion and only a negligible proportion by soil formation processes. Both bed load and suspension load are brought by melt water streams from beneath the glaciers. The melt waters run into glacially eroded lakes, where most of the coarse sediment material and some of the clay fraction is trapped. Most of the clay fraction remains in suspension, however, and is transported downstream to sea level. Considerable amounts of clay in suspension are carried far into the fjords.

\section{Mineralogical composition}

The grain size distribution, determined by settling tube techniques is shown by cumulative curves for a number of samples in fig. 46. The median grain sizes (dso) range from less than $1 \mu$ to $10 \mu$. Most of the samples are thus fine to medium-grained silts. The curves have a nearly perfect symmetry and approximate very closely to log-normal distribution.

The mineral composition of the muds was evaluatad by X-ray diffraction methods; mineral composition and chemical data of some samples are listed in Table 18. The sediments are composed of biotite, hornblende, chlorite, quartz and feldspar. Since the evaluation of potash-feldspar in the presence of plagioclase cannot be accomplished unequivocally by X-ray methods, no differentation has been made between the two feldspars.

The abundance of all the constituents is very uniform throughout the sampled area. 


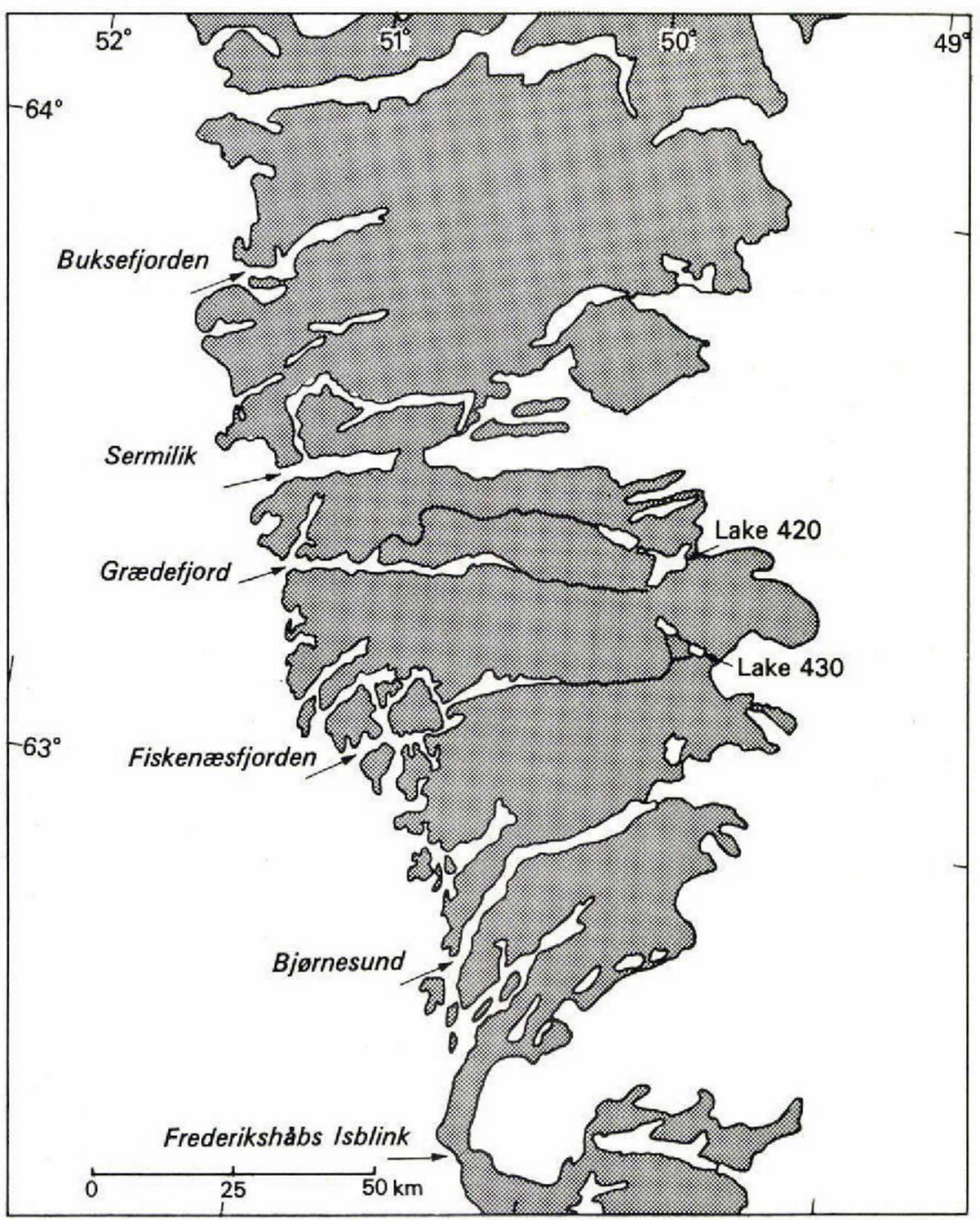

Fig. 45. Location map of investigated sediments in the Fiskenæsset region, southern West Greenland.

There is no difference qualitatively or quantitatively in the composition of the muds from lakes, the various fjords, or from off-shore locations. The effect of the salinity of sea water has not caused any detectable mineral alteration. The compositional uniformity of the sediments demonstrates that:

1. There is no detectable mineralogical alteration during the downstream transport by the melt water.

2. The suspended material is dispersed to such an extent that differences in bedrock composition are no longer reflected.

The sedimentary material is considered to have been produced solely by the mechani- 


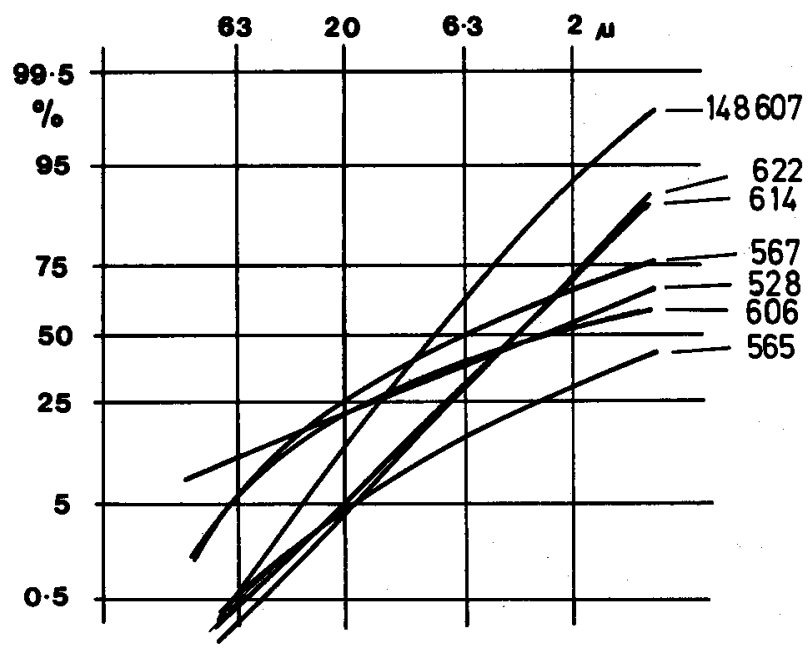

Fig. 46. Grain size distribution of some mud samples.

cal crushing, grinding, and milling action of moving ice. There is no kaolinite included in the muds, indicating that climatic factors were inappropriate for kaolinisation of feldspar.

The mineralogical analysis was focused on the biotite since, like hornblende, this mineral is most susceptible to weathering; hornblende, however, is difficult to analyse by X-ray techniques. The $(060)$ reflection of the biotite was found to lie between 1.5405 and 1.5432 $\AA$, which according to Eugster \& Wones (1958) corresponds to a biotite composed of 30 to $70 \%$ annite. A similar composition was evaluated by a correlation suggested by Grim

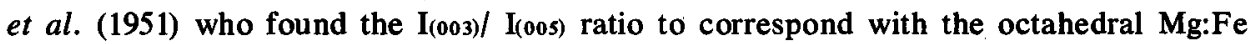
ratio. The $\mathrm{I}(003) / \mathrm{I}(005)$ ratio of the investigated biotites ranges from 5 to 10 corresponding to a $\mathrm{Mg}: \mathrm{Fe}$ ratio of $1: 2$.

The (001) peak of the biotite does not shift on ethylene glycol treatment indicating that there are no expandable layers within the biotite. In comparison with fresh biotite the (001) peak of the mineral is slightly broadened due to minor lattice disorder. For further evaluation of the biotite composition its potassium content was determined by atomic absorption spectroscopy. $\mathrm{K}_{2} \mathrm{O}$ contents of the biotite range from 4.6 to $10.8 \%$ with a mean at $6.4 \%$. The potassium content of biotite from the bedrock gneisses of the Fiskenæsset region (samples supplied by $\mathrm{F}$. Kalsbeek) was found to average $5.6 \% \mathrm{~K}_{2} \mathrm{O}$. Only two fresh biotites had $7.5 \% \mathrm{~K}_{2} \mathrm{O}$. Evidently the biotites of the sediments have not suffered any loss in potassium during transport by ice and water. The potassium concentration of the waters in the Fiskenæsset region (F. Kalsbeek, personal communication) is lower than the global average for rivers.

Since the bedrock biotites have a somewhat lower potassium content than commonly found in biotites from metamorphic rocks (8-9\% $\mathrm{K}_{2} \mathrm{O}$; Deer et al., 1962) the former are considered to have lost some of their potassium by leaching prior to glacial erosion.

The dehydration data (DTA) of the biotites derived from the sediments (fig. 47) are almost identical with those of the bedrock mica which gives further support for the conclusion that no significant $\mathrm{K}$-loss has been caused by either erosion or transport.

Determination of the cation exchange capacity and of the specific surface area as measured by BET methods (Brunnauer et al. 1938) was also carried out on the biotite. The 
Table 18. Composition and chemical data of the less than $2 \mu$ fraction of mud samples

\begin{tabular}{|c|c|c|c|c|c|c|c|c|c|c|c|}
\hline Lab. No. & Biot. & $\begin{array}{l}\text { Compos } \\
\text { Lay frac } \\
\text { Chlor. }\end{array}$ & $\begin{array}{l}\text { sition } \\
\text { ction } \\
\text { Hbld. }\end{array}$ & $\begin{array}{l}\text { of } \\
(<2 m y) \\
\text { Qtz. }\end{array}$ & Fdsp. & $\begin{array}{c}\text { Median } \\
\text { grain size } \\
\mu\end{array}$ & $\frac{I(003)}{I(005)}$ & $\begin{array}{c}\mathrm{d}(000) \\
\AA\end{array}$ & $\begin{array}{l}C E C \\
\frac{m e g}{100 g}\end{array}$ & $\begin{array}{l}\text { Spec. surf. } \\
\text { area (BET) } \\
\frac{\mathrm{m}^{2}}{g}\end{array}$ & $\begin{array}{l}x \text { content of } \\
\text { biotite in clay } \\
\text { fract. क } \mathrm{K}_{2} \mathrm{O}\end{array}$ \\
\hline 19 & 50 & 15 & 15 & 5 & 15 & 2.7 & 5.5 & 1.5405 & & & 5.4 \\
\hline 25 & 50 & 15 & 15 & 5 & 15 & & 4.5 & & & 20.1 & 5.8 \\
\hline 56 & 65 & 10 & 10 & 5 & 10 & & 9.5 & 1.5452 & & 20.7 & 4.6 \\
\hline 61 & 65 & 5 & 10 & 5 & 15 & 6.0 & 10.0 & 1.5452 & & $24 \cdot 9$ & 5.4 \\
\hline 63 & 65 & 10 & 10 & 5 & 10 & & 11.0 & 1.5452 & 27.3 & & 4.5 \\
\hline 91 & 65 & 10 & 5 & 5 & 15 & & 2.0 & 1.5428 & 45.2 & & 5.5 \\
\hline 102 & 60 & 10 & 10 & 5 & 15 & 2.7 & 4.5 & 1.5440 & 38.8 & 26.9 & 5.7 \\
\hline 104 & 65 & 10 & 15 & 5. & 10 & 8.0 & 5.5 & 1.5405 & & 17.5 & 4.5 \\
\hline 111 & 60 & 10 & 10 & 5 & 15 & 3.5 & 7.0 & 1.5428 & & 20.1 & 5.5 \\
\hline 119 & 65 & 10 & 10 & 5 & 10 & 3.5 & 9.0 & 1.5405 & 34.4 & & 5.1 \\
\hline 122 & 50 & 5 & 25 & 5 & 15 & & 8.5 & 1.5405 & & & 5.8 \\
\hline
\end{tabular}



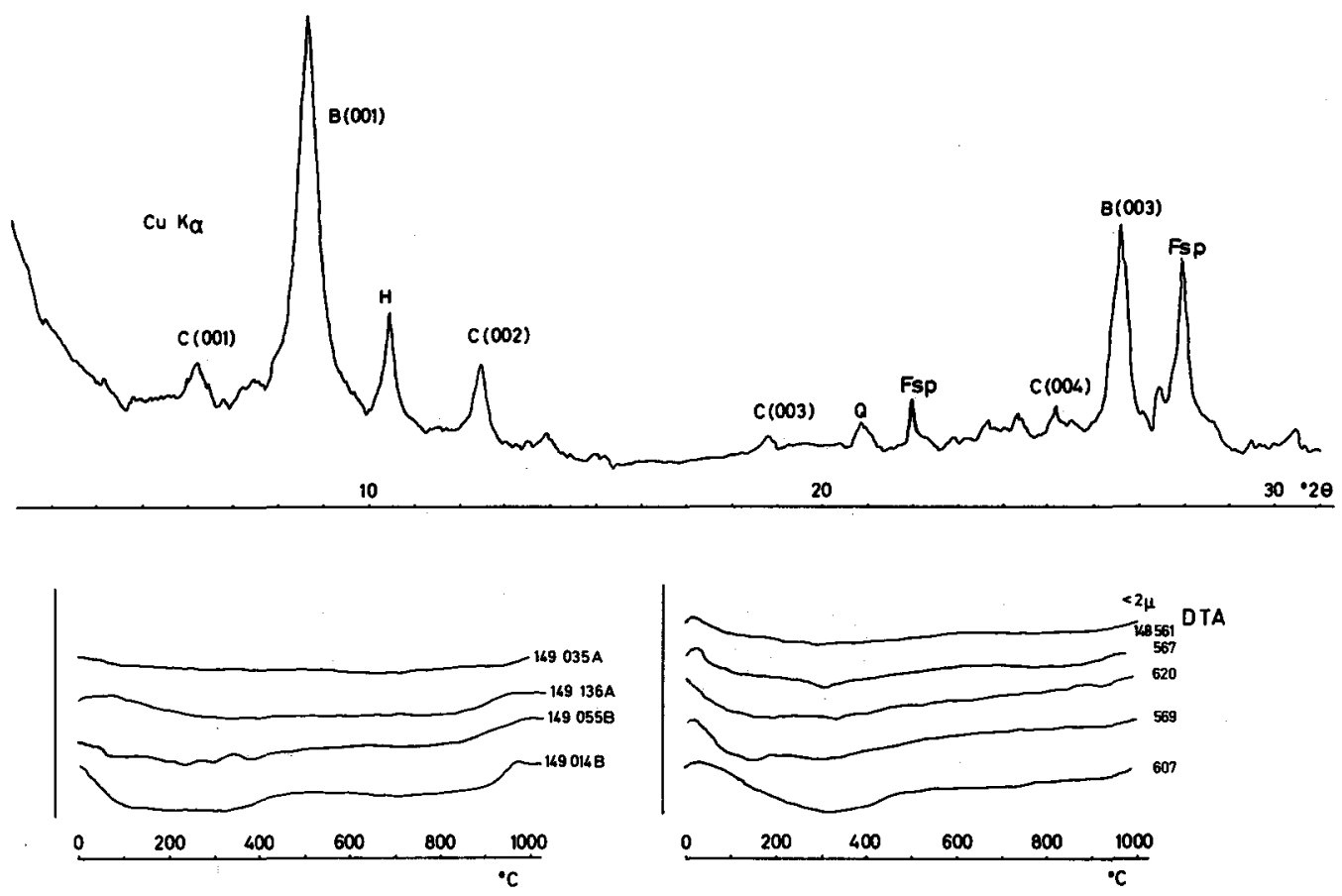

Fig. 47. X-ray diffraction pattern of the less than $2 \mu$ fraction of a typical mud sample and DTA tracings of biotite from bedrock gneiss and mud.

cation exchange capacity of the minus $2 \mu$ fraction was found to range from 7.9 to 49.5 $\mathrm{meq} / 100 \mathrm{~g}$ corresponding with the biotite abundance in the clay fraction. The specific surface area is dominantly controlled by the grain size distribution and varies between 17 and $27 \mathrm{~m}^{2} / \mathrm{g}$.

No attention has yet been given to the organic matter included in the sediments, which should be the subject of future investigations.

The quantitative composition of the sediments was also determined by X-ray methods. The abundances of the different minerals were calculated from the peak areas in relation to calibration curves obtained from pure mineral fractions as suggested by Gibbs (1967). The maximum error of the results from this method is $\pm 10 \%$ since differences in grain size and sample preparation may interfere.

The quantitative composition of seven samples divided into five size fractions is shown in fig. 48. With increasing grain size the proportion of biotite decreases whereas that of feldspar and quartz increases. The hornblende proportion is more or less independent of grain size.

The size fractionation was undertaken by sedimentation analyses in settling tubes. Due to the higher specific gravity of the hornblende in relation to quartz the actual grain size of hornblende is smaller than that of quartz in the same fraction. However, this has little bearing on the conclusions drawn from the evaluated compositions since in natural sedimentation processes hornblende will join the same size fractions.

The mineral distribution of the clay and silt size fractions as shown agrees closely with 


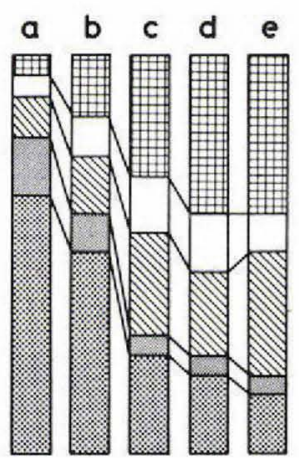

Sample- No. 148528

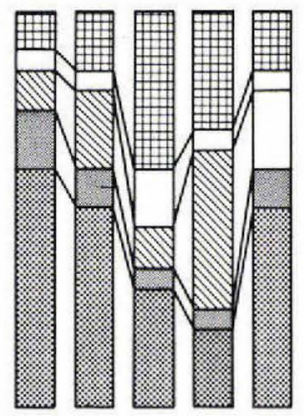

148607

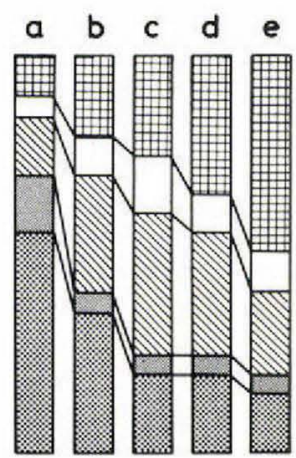

148565

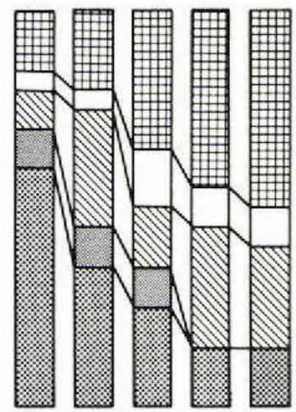

148614

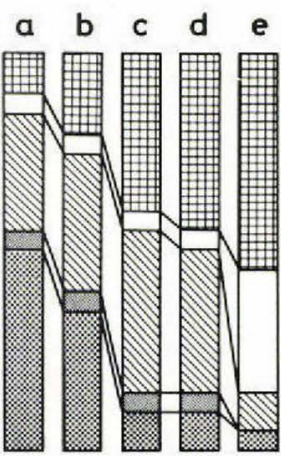

148567

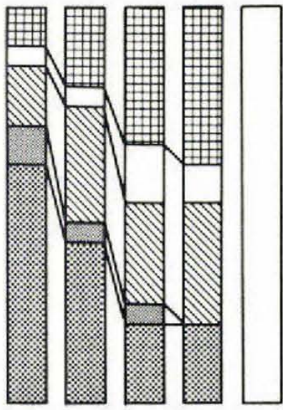

14862

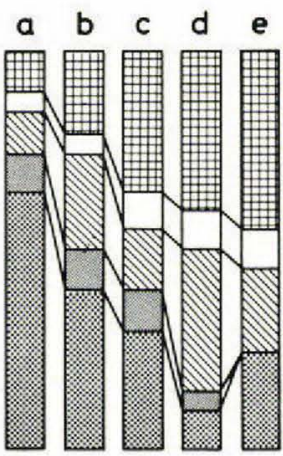

148606

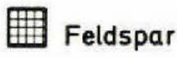

Quartz

Hornblende

Chlorite

Biotite

a: $<2 \mu$

b: $\quad 2-6,3 \mu$

c: $\quad 6.3-20 \mu$

d: $20-63 \mu$

$\mathrm{e}:>63 \mu$

Fig. 48. Composition of different grain size fractions of some mud samples.

the composition of sands as given by Kalsbeek et al. (1974). In fig. 49 the average composition of the clay, silt, and sand fractions is compared with the average bedrock composition in the Fiskenæsset region. There is a systematic variation in the mineral abundances from bedrock to clay size fraction of the sediments: feldspar and quartz decrease, hornblende has a maximum in the silt size fraction, and biotite while almost absent in the sands becomes more abundant as grain size decreases.

The mineral distribution as a function of grain size is considered to depend mainly on the mechanical stability of the different minerals. On the basis of the mineral distribution in relation to grain size the following order of increasing mechanical persistance can be established: biotite, hornblende, feldspar, quartz.

In contrast to sediments in temperate regions the recent silts and sands of the Fiskenæsset region have been formed without interference of chemical weathering processes. Therefore, the compositional differences between bedrock and sediment are related solely to transport selection. The compositional correspondance between bedrock and sand, as shown by Kalsbeek et al. (1974) no longer holds for the finer grained sediments. Regional differences in bedrock composition are not reflected by silt or clay composition since silt and clay, being transported in suspension, are dispersed almost homogeneously throughout the area. 
106

Table 19. Average chemical composition of bedrock and clay fraction as calculated from average mineralogical composition

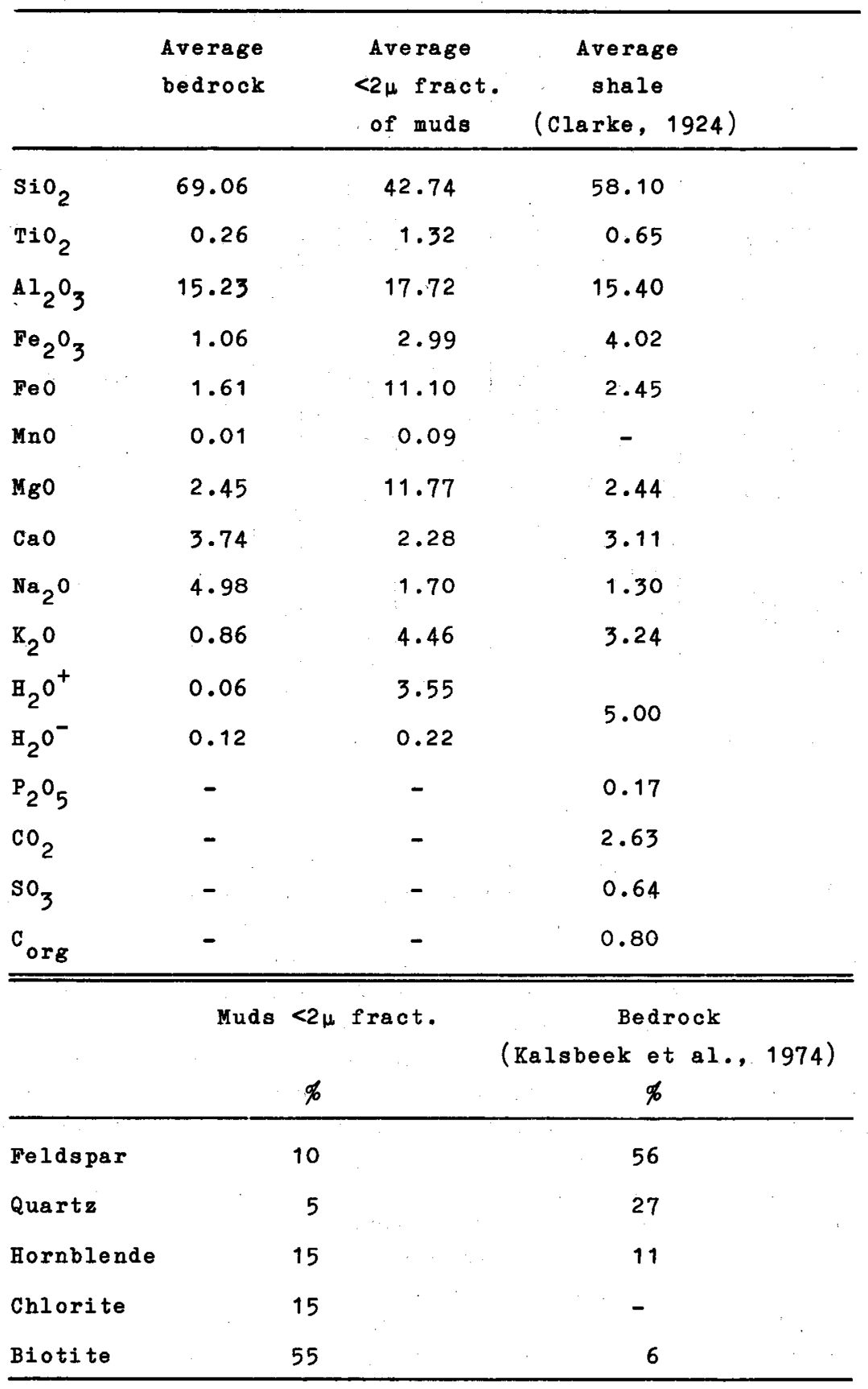

Gross chemical composition estimated from average mineralogical composition 
Fig. 49. Average composition of bedrock and sand, silt, and clay fractions of sediments derived from the bedrock.

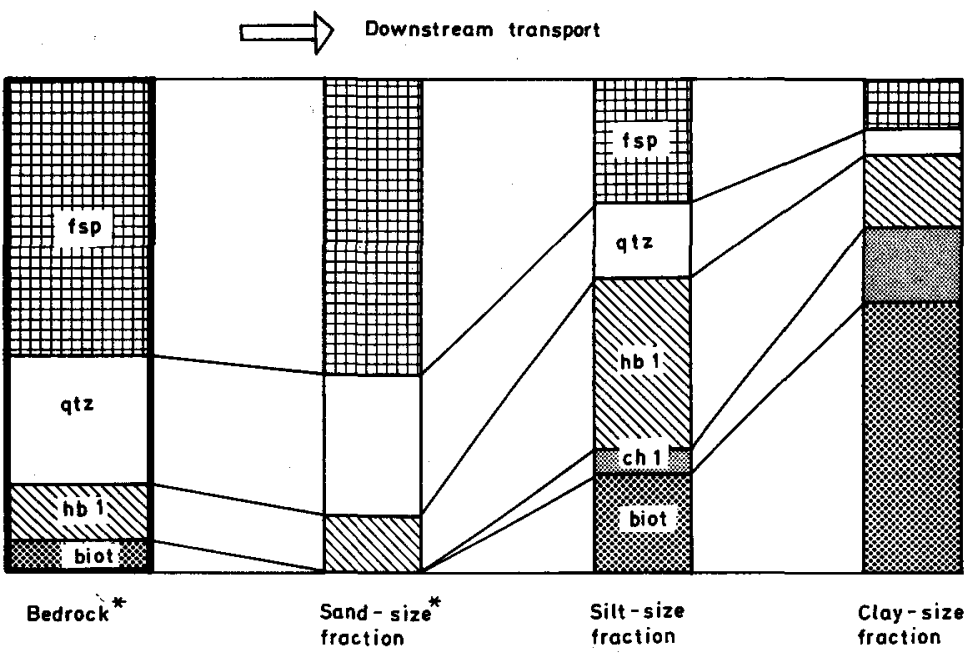

*after Kalsbeek et al. (1974)

\section{Chemical composition}

As a rough approach the average chemical analyses of both the bedrock and the minus $2 \mu$ fraction of the sediments were calculated from the average mineral composition (Table 19). Comparison of the results indicates that the clay fraction is impoverished in silica and sodium but is enriched in iron, magnesium, potassium and aluminium.

The cited composition of the 'average shale' is to be considered in relation to grain size in that 'average shale' consists of a dominant portion of silt in which the proportion of alkalis and alkali earths has been increased. True residual clays are extremely low in these elements and high in aluminum. The composition of the mechanically derived sediments from the Fiskenæsset region is naturally in strong contrast to the highly aluminous clays produced under conditions of intense chemical weathering. The Fiskenæsset sediments supply valuable data as to the relationships of clays associated with very immature sands, in particular, because these sediments have neither been influenced by the environment of deposition (due to their recent age) nor by diagenesis.

\section{References}

Brunnauer, S., Emmett, P. H. \& Teller, E. 1938: Adsorption of gases in multimolecular layers. $J$. Amer. chem. Soc. 60, 209-319.

Clarke, F. W. 1924: Data of geochemistry. Bull. U. S. geol. Surv. 770.

Deer, W. A., Howie, R. A. \& Zussman, J. 1962: Rock-forming minerals. 3, sheet silicates. London: Longmans.

Eugster, H. P. \& Wones, D. R. 1958: Phase relations of hydrous silicates with intermediate Mg/Fe ratios. Ann. Rep. Dir. Geophys. Lab. 57, 193 only. 
Gibbs, R. J. 1967: Quantitative X-ray diffraction analysis using clay mineral standards extracted from the samples to be analysed. Clay Miner. 7, 79-90.

Grim, R. E., Bradley, W. F. \& Brown, G. 1951: The mica clay minerals. In Brindley, G. W. (edit.) $X$-ray identification and structures of clay minerals. 138-172. Miner. Soc. Great Britain Monograph. Kalsbeek, F., Ghisler, M. \& Thomsen, B. 1974: Sand analysis as a method of estimating bedrock compositions in Greenland, illustrated by fluvial sands from the Fiskenæsset region. Bull. Grønlands geol. Unders. 111 (also Meddr Grønland 201,1) 32 pp. 